\title{
Life Cycle Assessment of Anaerobic Digestion of Municipal Waste for Vehicle Biogas Production
}

\author{
Huang Wei ${ }^{1, a^{*}}$, Zhang $\mathrm{Xin}^{2, \mathrm{~b}}$ \\ (School of Mechanical, Electronic and Control Engineering, Beijing Jiaotong University. Beijing, \\ 100044,China) \\ a10116327@bjtu.edu.cn, bzhangxin@bjtu.edu.cn
}

\begin{abstract}
Keywords: municipal waste; anaerobic digestion; vehicle biogas
\end{abstract}
Abstract. Using ISO life cycle analysis and assessment methods, life cycle assessment (LCA) of anaerobic digestion of municipal waste for vehicle biogas production in Anyang was studied. Through the confirmation of the goal and scope, the inventory analysis and environment impact potential calculation were made to the vehicle biogas production process of anaerobic digestion of municipal waste. The results show that the maximum pollution emissions is in vehicle operation phase, and the maximum energy consumption is in vehicle biogas production phase, and the maximum contributions to environmental impact load is global warming, and the biogas generated by anaerobic digestion of municipal waste fully meets national standards for vehicle compressed natural gas. Finally According to life cycle inventory and environment impact assessment the analysis and suggestions were made to the city decision makers

\section{Introduction}

With the growing of urban population and the improvement in the living standards, the urban garbage increases, and the type of garbage is diverse. Garbage piled up everywhere affects the appearance of people living environment, and garbage stench also affects quality of life. Therefore, the garbage problem has become one of the important cities of livelihood issues ${ }^{[1,2]}$

The current study on life cycle assessment (LCA) of urban waste only focus on waste composting, incineration and landfill garbage technology $y^{[3]}$, and the waste disposal method is included sanitary landfill, incineration and aerobic composting. These studies usually consider the different waste management, including waste sorting and collection, waste transportation routes minimization, recycling and even recyclable materials ${ }^{[4]}$, and scope of the study includes from the beginning of waste generating to waste exhausted in the whole garbage disposal process ${ }^{[5]}$. Research on LCA of anaerobic fermentation of municipal waste for vehicle biogas production is lacked. In this study, energy consumption and environmental pollution emissions of LCA of vehicle biogas production for anaerobic fermentation of municipal waste was studied, and assuming the municipal waste components used in landfill and incineration after sorting were excluded, and the organic waste components directly used for vehicle biogas production material. This study provides theory basis and feasible measure for the use of vehicle biogas produced by anaerobic fermentation of municipal waste and reducing pollution.

\section{LCA theoretical framework}

Accordance with the parameters model of the IS014040 standard, the LCA procedure of vehicle biogas produced by anaerobic fermentation of municipal waste can be divided into four steps: determination of the objectives and scope, inventory analysis, impact assessment and interpretation of the life cycle.

The goal of LCA of anaerobic fermentation of municipal waste for vehicle biogas production is aimed at analysis and evaluation of the input and output material and energy, and the influence of pollutants on the environment. 
The scope of municipal waste producing biogas as shown in Fig.1, the main frame consists of three stages: raw materials stages, fuel stages and automobile operation stages, where the raw material stage includes municipal waste collection, sorting and crushing; the fuel stage includes biogas production, biogas purification, biogas storage; the automobile operation stage only refers to the car use. The main purpose of this paper is to study on energy consumption and environmental emissions of whole life cycle for vehicle biogas from the raw material acquisition to biogas consumed completely, therefore, the components of municipal waste used for incineration and landfill after garbage sorting will not be considered. It is supposed that the organic waste components after garbage sorting will be directly used for biogas production. The life cycle upstream include two stages: raw material stage and fuel stage, and the downstream stage include automobile manufacturing, automobilism and vehicles scrap. The vehicle biogas belongs to new energy fuel, and the biogas vehicle is still in the trial stage or small-scale applications, due to economies of scale are not yet reflected, it is difficult to estimate impact of the vehicle's production, operation, maintenance, and scrap auto recycling. Therefore, this study is aimed at the upstream phase.

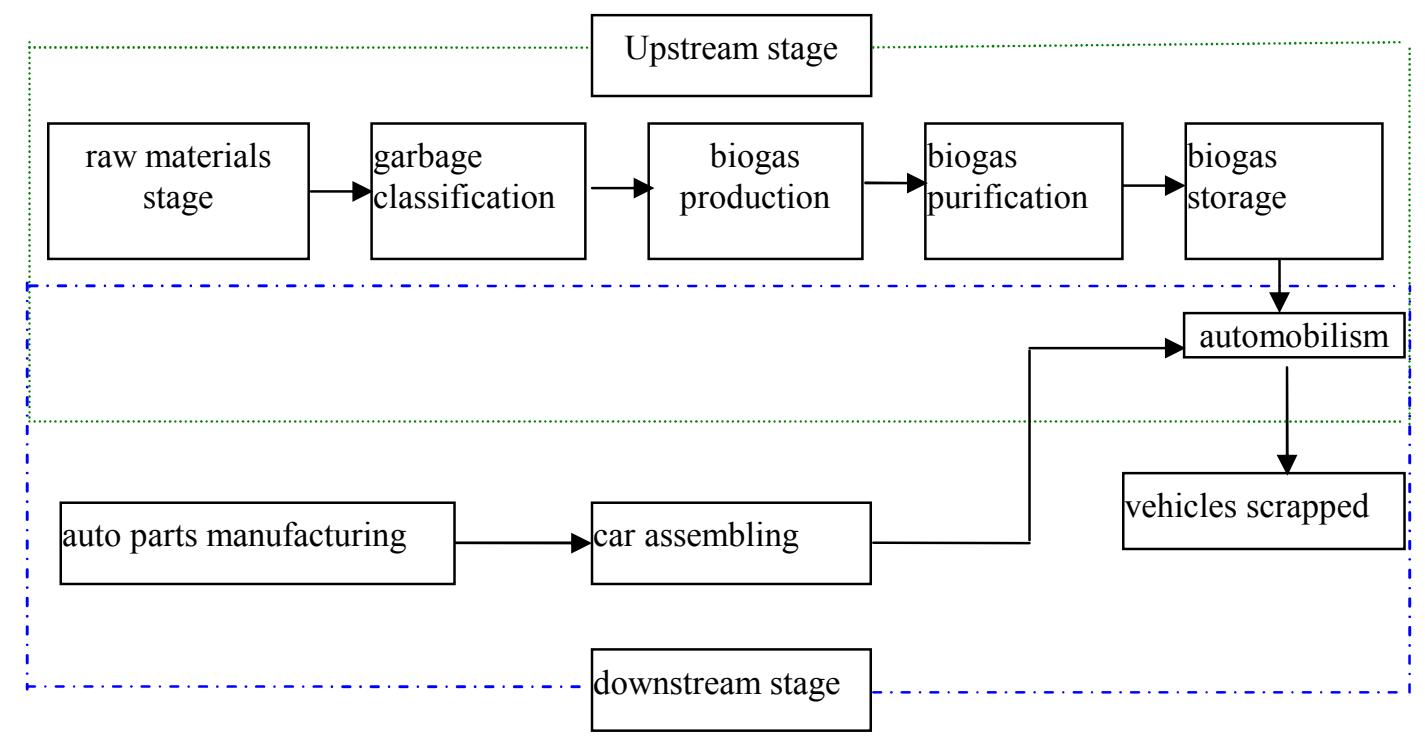

Fig.1 System defined

\section{Life cycle inventory analysis of vehicle biogas}

With above method, Anyang garbage produced biogas plant is computed and analyzed for example. This plant covers an area of 67 acres, and its design life is 20 years, and its design waste disposal capacity of $700 \mathrm{t} / \mathrm{d}$ and annual capacity of $12,775,000 \mathrm{~m}^{3}$ vehicle biogas. Except vehicle biogas, solid fertilizer, liquid fertilizer and $\mathrm{CO}_{2}$ are also produced. In vehicle operation phase, the data collection for energy consumption and pollutant emissions is from experimental methods. And experimental study on the biogas fuel consumption and environmental emissions of city bus was analyzed through the ordinary road tests, and the test results are shown in Table 1. 
Table 1 Energy consumption and pollutant emission of each stage

\begin{tabular}{|c|c|c|c|c|c|c|c|c|c|c|c|}
\hline Name & $\begin{array}{l}\text { Fuel } \\
\text { type }\end{array}$ & $\begin{array}{c}\text { energy } \\
\text { consum } \\
\text { ption }\end{array}$ & $\begin{array}{l}\mathrm{CO}_{2} \\
\mathrm{~kg} / \mathrm{t}\end{array}$ & $\begin{array}{l}\text { NMHC } \\
\mathrm{kg} / \mathrm{t}\end{array}$ & $\begin{array}{l}\mathrm{CO} \\
\mathrm{kg} / \mathrm{t}\end{array}$ & $\begin{array}{l}\mathrm{NO}_{X} \\
\mathrm{~kg} / \mathrm{t}\end{array}$ & $\begin{array}{l}\text { PM10 } \\
\mathrm{kg} / \mathrm{t}\end{array}$ & $\begin{array}{l}\mathrm{SO}_{2} \\
\mathrm{~kg} / \mathrm{t}\end{array}$ & $\begin{array}{l}\mathrm{CH}_{4} \\
\mathrm{~kg} / \mathrm{t}\end{array}$ & $\begin{array}{l}\mathrm{NH}_{3} \\
\mathrm{~kg} / \mathrm{t}\end{array}$ & $\begin{array}{l}\mathrm{H}_{2} \mathrm{~S} \\
\mathrm{~kg} / \mathrm{t}\end{array}$ \\
\hline $\begin{array}{l}\text { Garbage } \\
\text { truck }\end{array}$ & $\begin{array}{l}\text { diese } \\
1\end{array}$ & $\begin{array}{l}1.2 \\
\text { L. } \mathrm{t}^{-1}\end{array}$ & $\begin{array}{l}1.520 \\
4\end{array}$ & 0.0009 & $\begin{array}{l}0.004 \\
6\end{array}$ & 0.0018 & $\begin{array}{l}0.003 \\
9\end{array}$ & $\begin{array}{l}0.001 \\
2\end{array}$ & $\begin{array}{l}0.001 \\
5\end{array}$ & $\begin{array}{l}0.004 \\
5\end{array}$ & $\begin{array}{l}0.008 \\
4\end{array}$ \\
\hline $\begin{array}{l}\text { Sorting } \\
\text { machine }\end{array}$ & $\begin{array}{l}\text { powe } \\
\mathrm{r}\end{array}$ & $\begin{array}{l}2.0 \\
\mathrm{~kW} \cdot \mathrm{h} \cdot \mathrm{t}^{-1}\end{array}$ & 1.524 & $\begin{array}{l}0.000 \\
582\end{array}$ & $\begin{array}{l}0.002 \\
3\end{array}$ & $\begin{array}{l}0.0090 \\
8\end{array}$ & $\begin{array}{l}0.006 \\
3\end{array}$ & $\begin{array}{l}0.008 \\
68\end{array}$ & $\begin{array}{l}0.012 \\
4\end{array}$ & $\begin{array}{l}0.005 \\
2\end{array}$ & $\begin{array}{l}0.006 \\
4\end{array}$ \\
\hline $\begin{array}{l}\text { Splintered } \\
\text { machine }\end{array}$ & $\begin{array}{l}\text { powe } \\
\text { r }\end{array}$ & $\begin{array}{l}1.7 \\
\text { kW.h.t. }\end{array}$ & $\begin{array}{l}1.295 \\
4\end{array}$ & $\begin{array}{l}0.0004 \\
947\end{array}$ & $\begin{array}{l}0.001 \\
955\end{array}$ & $\begin{array}{l}0.0077 \\
18\end{array}$ & $\begin{array}{l}0.003 \\
4\end{array}$ & $\begin{array}{l}0.007 \\
378\end{array}$ & $\begin{array}{l}0.002 \\
6\end{array}$ & $\begin{array}{l}0.000 \\
8\end{array}$ & $\begin{array}{l}0.001 \\
1\end{array}$ \\
\hline $\begin{array}{l}\text { Pretreatment } \\
\text { of } \\
\text { fermentation } \\
\text { material }\end{array}$ & $\begin{array}{l}\text { powe } \\
\text { r }\end{array}$ & $\begin{array}{l}\text { 6/kW.h. } \\
\mathrm{t}^{-1}\end{array}$ & 4.572 & $\begin{array}{l}0.0017 \\
46\end{array}$ & $\begin{array}{l}0.006 \\
9\end{array}$ & $\begin{array}{l}0.0272 \\
4\end{array}$ & $\begin{array}{l}0.011 \\
4\end{array}$ & $\begin{array}{l}0.026 \\
04\end{array}$ & $\begin{array}{l}0.013 \\
8\end{array}$ & $\begin{array}{l}0.008 \\
6\end{array}$ & $\begin{array}{l}0.004 \\
7\end{array}$ \\
\hline $\begin{array}{l}\text { Anaerobic } \\
\text { fermentation }\end{array}$ & $\begin{array}{l}\text { powe } \\
\mathrm{r}\end{array}$ & $\begin{array}{l}\text { 13/kW. } \\
\text { h. } \mathrm{t}^{-1}\end{array}$ & 9.906 & $\begin{array}{l}0.0037 \\
83\end{array}$ & $\begin{array}{l}0.014 \\
95\end{array}$ & $\begin{array}{l}0.0590 \\
2\end{array}$ & $\begin{array}{l}0.024 \\
7\end{array}$ & $\begin{array}{l}0.056 \\
42\end{array}$ & $\begin{array}{l}0.029 \\
9\end{array}$ & $\begin{array}{l}0.001 \\
2\end{array}$ & $\begin{array}{l}0.002 \\
4\end{array}$ \\
\hline $\begin{array}{l}\text { Biogas } \\
\text { storage, } \\
\text { purification } \\
\text { and } \\
\text { distribution }\end{array}$ & $\begin{array}{l}\text { powe } \\
\mathrm{r}\end{array}$ & $\begin{array}{l}\text { 4/kW.h. } \\
\mathrm{t}^{-1}\end{array}$ & 3.028 & $\begin{array}{l}0.0011 \\
64\end{array}$ & $\begin{array}{l}0.004 \\
6\end{array}$ & $\begin{array}{l}0.0181 \\
6\end{array}$ & $\begin{array}{l}0.007 \\
6\end{array}$ & $\begin{array}{l}0.017 \\
36\end{array}$ & $\begin{array}{l}0.009 \\
2\end{array}$ & $\begin{array}{l}0.003 \\
2\end{array}$ & $\begin{array}{l}0.001 \\
5\end{array}$ \\
\hline $\begin{array}{l}\text { Post-treatme } \\
\text { nt of } \\
\text { anaerobic } \\
\text { digestion } \\
\text { fluid }\end{array}$ & $\begin{array}{l}\text { powe } \\
\mathrm{r}\end{array}$ & $\begin{array}{l}\text { 2/kW.h. } \\
\mathrm{t}^{-1}\end{array}$ & 1.524 & $\begin{array}{l}0.000 \\
582\end{array}$ & $\begin{array}{l}0.002 \\
3\end{array}$ & $\begin{array}{l}0.0090 \\
8\end{array}$ & $\begin{array}{l}0.003 \\
8\end{array}$ & $\begin{array}{l}0.008 \\
68\end{array}$ & $\begin{array}{l}0.006 \\
7\end{array}$ & $\begin{array}{l}0.001 \\
6\end{array}$ & $\begin{array}{l}0.002 \\
1\end{array}$ \\
\hline $\begin{array}{l}\text { CJ6110G1Y } \\
10 \mathrm{H} \text { bus }\end{array}$ & $\begin{array}{l}\text { bioga } \\
\text { s }\end{array}$ & $\begin{array}{l}220 \mathrm{~g} / \mathrm{k} \\
\mathrm{Wh}\end{array}$ & $\begin{array}{l}59.46 \\
6\end{array}$ & 0.2355 & $\begin{array}{l}0.071 \\
6\end{array}$ & $\begin{array}{l}0.1669 \\
5\end{array}$ & $\begin{array}{l}0.001 \\
8\end{array}$ & $\begin{array}{l}0.015 \\
6\end{array}$ & $\begin{array}{l}0.235 \\
5\end{array}$ & $\begin{array}{l}0.000 \\
9\end{array}$ & $\begin{array}{l}0.000 \\
8\end{array}$ \\
\hline
\end{tabular}

\section{Life cycle impact assessment of vehicle biogas}

The influence on life cycle is divided into three classes: impact on resources, human health and ecological health. The classification is categorized the input and output data of LCI into different types of environmental impact. The characterization is put different material for each of the three categories convert to a unified unit. Standardization and weight evaluation is to determine the relative contribution or weight of different type of environment impact so as to obtain full environmental impact of system.

The vehicle biogas production system from anaerobic fermentation of municipal waste include resource consumption and environment impact of various gases, which is divided into three types, including global warming, acidification and eutrophication which were characterized with reference of $\mathrm{CO}_{2} 、 \mathrm{SO}_{2}$ and $\mathrm{NO}_{3}{ }^{-}$respectively. Potential environmental impact value means summation of all environmental emissions in the whole product system. The sum of the environmental emissions formulated as

$$
E(i)=\sum E(i)_{j}=\sum\left(q_{j} \times \lambda\right)
$$

In the formula, where $E$ (i) is i-kind of potential environmental impact value for production systems; $q_{i}$ is $j$-kind of substance emissions; $\lambda$ is equivalent factor that $\mathrm{j}$-kind of substance emissions influence on i-kind of potential environmental impact. The equiv relationship between each environmental impact factor and their reference is shown in Table 2 
After standardization, the environmental impact potential values of this production system and weighting factor are used with literature calculation method ${ }^{[1]}$, the results are shown in Table 2.

Table 2 Environmental impact load

\begin{tabular}{|c|c|c|c|c|c|c|c|c|c|c|}
\hline Effect Type & \multicolumn{4}{|c|}{ Global warming potential } & \multicolumn{4}{|c|}{ Acid potential } & \multicolumn{2}{|c|}{$\begin{array}{c}\text { Eutrophication } \\
\text { potential }\end{array}$} \\
\hline Impact factors & $\mathrm{CO}_{2}$ & $\mathrm{CH}_{4}$ & $\mathrm{CO}$ & $\mathrm{NO}_{\mathrm{X}}$ & $\mathrm{NO}_{\mathrm{X}}$ & $\mathrm{SO}_{2}$ & $\mathrm{NH}_{3}$ & $\mathrm{H}_{2} \mathrm{~S}$ & $\mathrm{NO}_{\mathrm{X}}$ & $\mathrm{NH}_{3}$ \\
\hline Object of reference & \multicolumn{4}{|c|}{$\mathrm{CO}_{2}$} & \multicolumn{4}{|c|}{$\mathrm{SO}_{2}$} & \multicolumn{2}{|c|}{$\mathrm{NO}_{3}^{-}$} \\
\hline Coefficient & 1 & 25 & 2 & 320 & 0.7 & 1 & 1.88 & 1.88 & 1.35 & 3.64 \\
\hline \multirow[t]{2}{*}{ Emissions $\mathrm{kg} / \mathrm{t}$} & 60.9 & 0.24 & 0.07 & 0.1688 & 0.1688 & 0.001 & 0.00 & 0.00 & 0.1688 & 0.0076 \\
\hline & 864 & 95 & 62 & & & 2 & 76 & 96 & & \\
\hline Impact potentials & \multicolumn{4}{|c|}{121.3915} & \multicolumn{4}{|c|}{0.1517} & \multicolumn{2}{|c|}{0.2555} \\
\hline $\begin{array}{l}\text { Standardization base } \\
\text { value }\end{array}$ & \multicolumn{4}{|c|}{8700} & \multicolumn{4}{|c|}{35} & \multicolumn{2}{|c|}{59} \\
\hline $\begin{array}{l}\text { Standard potential } \\
\text { value }\end{array}$ & \multicolumn{4}{|c|}{$1.4 \times 10^{-2}$} & \multicolumn{4}{|c|}{$4.3 \times 10^{-3}$} & \multicolumn{2}{|c|}{$4.3 \times 10^{-3}$} \\
\hline Weight factor & \multicolumn{4}{|c|}{0.83} & \multicolumn{4}{|c|}{0.73} & \multicolumn{2}{|c|}{0.73} \\
\hline Load effect & \multicolumn{4}{|c|}{$1.2 \times 10^{-2}$} & \multicolumn{4}{|c|}{$3.2 \times 10^{-3}$} & \multicolumn{2}{|c|}{$3.2 \times 10^{-3}$} \\
\hline Summation & \multicolumn{10}{|c|}{$1.84 \times 10^{-2}$} \\
\hline
\end{tabular}

As seen from Table 2, under the environment impact load of anaerobic fermentation of municipal waste for vehicle biogas production, the environmental impact load of global warming is the largest. This is because the main component of vehicle biogas from anaerobic fermentation of municipal waste is methane whose complete combustion product is carbon dioxide, and both of methane and carbon dioxide are important greenhouse gases.

\section{Conclusion}

(1) In anaerobic fermentation of municipal waste for vehicle biogas production life cycle, the maximum pollution emissions is in vehicle operation phase, so the key of reducing environmental pollutions is to improve biogas fuel combustion system or advance new automotive technology.

(2) In anaerobic fermentation of municipal waste for vehicle biogas production life cycle, the maximum energy consumption is in vehicle biogas production phase, where the most energy consumption is in anaerobic fermentation process. How to reduce the power consumption of the device, or to improve production processes to reduce electrical consumption, is the main way to reduce energy consumption.

(3) In anaerobic fermentation of municipal waste for vehicle biogas production life cycle, the maximum contributions to environmental impact load is global warming, that is the same for acidification and eutrophication.

(4) It is more scientific, reasonable and feasible for urban waste disposal from landfill and incineration into anaerobic fermentation, which can be used as reference for urban waste disposal decisions.

\section{References}

[1]YANG Jianx in, WANG Rusong, LIU Jingru. Methodology of life cycle impact assessment for Chinese products,J. ACTA SCIENTIAE CIRCUMSTANTIAE, 2001,21(2):234 237.

[2]Birgisdóttir H.Life cycle assessment of disposal of residues from municipal solid waste incineration: Recycling of bottom ash in road construction or landfilling in Denmark evaluated in the ROAD-RES model ,J. Waste Management, 2007,25(27):75-84. 
[3]M.C.Reich. Economic assessment of municipal waste management systems---case studies using a combination of life cycle assessment (LCA) and life cycle costing (LCC), J. Journal of Cleaner Production.2005,13(6):253-263.

[4]Chaya W., Gheewala S. H. Life cycle assessment of MSW-to-energy schemes in Thailand, J.Journal of Cleaner Production,2007,15(15):1463-1468.

[5] Kim M.H., Kim J.W. Comparison through a LCA evaluation analysis of food waste disposal options from the perspective of global warming and resource recovery, J. Science of the Total Environment, 2010, 408(19): 3998-4006. 